\title{
Analysis of $\alpha 1$ and $\alpha 2$ globin genes among patients with hemoglobin Adana in Malaysia
}

T.Y. Lee ${ }^{1}$, M.I. Lai ${ }^{1}$, P. Ismail ${ }^{2}$, V. Ramachandran ${ }^{3}$, J.A.M.A. Tan ${ }^{4}$, L.K. Teh ${ }^{1,5}$, R. Othman ${ }^{6}$, N.H. Hussein ${ }^{6}$ and E. George ${ }^{1}$

1'Department of Pathology, Faculty of Medicine and Health Sciences, Universiti Putra Malaysia, Serdang, Selangor, Malaysia

${ }^{2}$ Department of Biomedical Science, Faculty of Medicine and Health Sciences, Universiti Putra Malaysia, Serdang, Selangor, Malaysia

${ }^{3}$ Malaysian Research Institute on Ageing, Universiti Putra Malaysia,

Serdang, Selangor, Malaysia

${ }^{4}$ Department of Biomedical Science, Faculty of Medicine,

University of Malaya, Kuala Lumpur, Malaysia

${ }^{5}$ Department of Biomedical Science, Faculty of Science,

Universiti Tunku Abdul Rahman, Kampar, Perak, Malaysia

${ }^{6}$ Department of Pathology, Hospital Kuala Lumpur, Kuala Lumpur, Malaysia

Corresponding author: E. George

E-mail: elzageorge21@gmail.com

Genet. Mol. Res. 15 (2): gmr.15027400

Received October 1, 2015

Accepted November 19, 2015

Published April 7, 2016

DOI http://dx.doi.org/10.4238/gmr.15027400

ABSTRACT. Hemoglobin (Hb) Adana [HBA2: c179G>A (or HBA1); p.Gly60Asp] is a non-deletional $\alpha$-thalassemia variant found in Malaysia. An improvement in the molecular techniques in recent years has made identification of $\mathrm{Hb}$ Adana much easier. For this study, a total of $26 \mathrm{Hb}$ Adana $\alpha$-thalassemia intermedia and $10 \mathrm{Hb}$ Adana trait blood samples were collected from patients. Common deletional and non-deletional $\alpha$-thalassemia genotypes were determined using multiplex gap polymerase chain reaction (PCR) and multiplex ARMS PCR techniques. Identification of the $\mathrm{Hb}$ Adana location on the $\alpha$-globin gene was carried out using genomic sequencing and the location of the mutation was confirmed via restriction fragment length polymorphismPCR. Among the 36 samples, $24(66.7 \%)$ had the $-\alpha^{3.7} / \alpha^{\mathrm{Cd} 59} \alpha$ mutation, while the $-\alpha^{3.7} / \alpha^{\mathrm{Cd} 59} \alpha$ mutation accounted for 2 samples (5.6\%) and the remaining 
$10(27.8 \%)$ samples were $\alpha / \alpha^{\text {Cd59 }} \alpha$. All 36 samples were found to have the $\mathrm{Hb}$ Adana mutation on the $\alpha 2$-globin gene. The position of the $\alpha$-globin gene mutation found in our cases was similar to that reported in Indonesia (16\%) but not to that in Turkey $(0.6 \%)$. Our results showed that the $\mathrm{Hb}$ Adana mutation was preferentially present in the $\alpha 2$-globin genes in Malays compared to the other ethnicities in Malaysia. Thus, the Malays might have similar ancestry based on the similarities in the $\mathrm{Hb}$ Adana position.

Key words: Hb Adana; $\alpha$-thalassemia; $\alpha$-globin genes; RFLP-PCR; Genotyping

\section{INTRODUCTION}

$\alpha$-thalassemia is a highly prevalent genetic disease that is characterized by various degrees of $\alpha$-globin chain deficiency caused either by deletional or non-deletional mutations. Nondeletional $\alpha$-mutations are denoted as $\alpha^{\top} \alpha$ or $\alpha \alpha^{\top}$ depending on the location of the mutation either on the $\alpha 2$ or $\alpha 1$ gene (Bain, 2006). Non-deletional mutations, which involve the $\alpha 2$ gene are often associated with more severe clinical phenotypes than the $\alpha 1$ gene, as the former encodes for 2-3 fold more $\alpha$-globin mRNA than the latter (Liebhaber et al., 1986). Hb Adana [HBA2: c179G>A (or HBA1); p.Gly60Asp] is a common non-deletional $\alpha$-thalassemia variant found among Malays (Rahimah et al., 2012). This highly unstable variant is located at position Cd 59 either on $\alpha 1-$ or $\alpha 2$-globin gene. This point mutation disrupts protein stability since it involves the substitution of the amino acid glycine with a charged aspartic acid (Cürük et al., 1993).

Thalassemia is a public health issue in Malaysia, because it has been estimated that a total of 3-4.5\% of Malays and Chinese are thalassemia carriers (George and Ann, 2010). The frequency of $\alpha$-thalassemia was found to be $4.1 \%$ in certain regions in Malaysia (Rahimah et al., 2012). The intermediate forms of $\alpha$-thalassemia are typically selected since the phenotypic changes are commonly observed in this group than that of the $\alpha$-thalassemia trait and $\mathrm{Hb}$ Barts hydrops fetalis patients. For $\alpha$-thalassemia trait, the phenotypes are normally too mild and it is difficult to observe any severe changes. Most of the $\mathrm{Hb}$ Barts hydrops fetalis patients die at a young age due to the severity of the disease (Weatherall, 1995). This study will be informative regarding the location of $\mathrm{Hb}$ Adana on the $\alpha$-globin gene in Malaysia and its origin compared to other $\mathrm{Hb}$ Adana studies.

\section{MATERIAL AND METHODS}

\section{Study subjects}

$\mathrm{Hb}$ Adana was identified in the samples sent to Hospital Kuala Lumpur for $\alpha$-thalassemia molecular studies. A total of $26 \alpha$-thalassemia intermedia with $\mathrm{Hb}$ Adana and $10 \mathrm{Hb}$ Adana trait blood samples were collected from patients at the Hospital Kuala Lumpur. This study was approved by the National Medical Research Register Ethics Committee (NMRR-12-1387-13958) and was performed in accordance with the Declaration of Helsinki. Verbal and written consent was obtained from all study subjects.

\section{DNA isolation}

A total of $2.5 \mathrm{~mL}$ venous blood was collected in EDTA-vacutainers from $\alpha$-thalassemia 
patients. Genomic DNA was extracted from leukocytes (in peripheral blood samples) using QIAamp DNA Midi kit (Qiagen GmbH, Hilden, Germany). Extracted genomic DNA was tested for its quality and quantity using Nanodrop 1000 Spectrophotometer (Thermo Scientific, Thermo Fisher Scientific Inc., Wilmington, DC, USA) and agarose gel electrophoresis.

\section{$\alpha$-globin genotyping}

Seven deletional $\alpha$-thalassemia [- $\alpha^{3.7}$ (NG_000006.1:g.34164_37967del3804), - $\alpha^{4.2}$ (not defined), ---SEA (NG_000006.1:g.26264_45564del19301), - $\alpha^{20.5}$ (NG_000006.1:g.15164_37864d el22701), ---THAI (NG_000006.1:g.10664_44164del33501), --FFL (NG_000006.1:g.11684_43534d el31851), ---MED (NG_000006.1:g.24664_41064del16401)] were characterized using multiplex gap polymerase chain reaction (PCR) (Chong et al., 2000).

Six point mutations [initiation Cd (c.1A>G), Cd30 (c.91_93delGAG), Hb Evora (c.106T>C), Hb Adana (c.179G $>A$ ), Hb Quong Sze (c.377T>C), Hb Constant Spring (c.427T>C)] were characterized using multiplex ARMS PCR (Eng et al., 2001).

\section{Detection of the location of $\mathrm{Hb}$ Adana in $\alpha 1-$ and $\alpha 2$-globin genes}

PCR products were purified, sent for bidirectional sequencing using BigDye Terminator v3.1 Cycle Sequencing Kit (Applied Biosystems, Warrington, UK) and analyzed on the ABI 3100 Genetic Analyzer (Applied Biosystems). The sequence alignment and assembly was done using the DNA Baser sequence assembly software (Heracle Biosoft SRL, Arges, Germany).

\section{Confirmation of Hb Adana on a2-globin gene}

Restriction fragment length polymorphism (RFLP)-PCR technique was performed to confirm the location of $\mathrm{Hb}$ Adana on the $\alpha 2$-globin gene as described by Nainggolan et al. (2010). The forward and reverse primers 59modF (5'-GCT CTG CCC AGG TTA AGG GCC TCG-3') and $\alpha 2 R$ (5'-GGG AGG CCC ATC GGG CAG GAG GAA C-3'), respectively, were used to amplify the 460-bp product using conventional PCR. PCR was performed in a $25-\mu \mathrm{L}$ reaction containing $2 \mathrm{X}$ Phusion Flash PCR Master Mix and 100 ng DNA template (Phusion Flash High-Fidelity PCR Master Mix, Thermo Scientific, Affibody AB, Sweden). PCR was carried out with an initial heat activation for $10 \mathrm{~s}$ at $98^{\circ} \mathrm{C}$, followed by 35 cycles of $98^{\circ} \mathrm{C}$ for $1 \mathrm{~s}, 58^{\circ} \mathrm{C}$ for $5 \mathrm{~s}$, and $72^{\circ} \mathrm{C}$ for $15 \mathrm{~s}$, and then an extension step of $72^{\circ} \mathrm{C}$ for 1 min using a PCR thermal cycler (Takara, Shiga, Japan). About $20 \mu \mathrm{L}$ PCR products was used for restriction enzyme digestion with Taq- ${ }^{\alpha} \mid$ enzyme (New England Biolabs, Beverly, MA, USA). A total of $5 \mu \mathrm{L}$ PCR product and the restricted fragments were examined on a $1.5 \%$ agarose gel, stained in ethidium bromide solution, and viewed under a UV illuminator.

\section{RESULTS}

This study recruited $26 \alpha$-thalassemia intermedia patients with $\mathrm{Hb}$ Adana and 10 patients with $\mathrm{Hb}$ Adana trait. Representative results are shown in Table 1 in which Malays had the highest frequency of the genotype $-\alpha^{3.7} / \alpha^{\mathrm{Cd59}} \alpha(66.7 \%)$, followed by $-\alpha^{4.2} / \alpha^{\mathrm{Cd} 59} \alpha(5.6 \%)$, and $\alpha \alpha / \alpha^{\mathrm{Cd59}} \alpha$ (27.8\%). Figure 1 shows the chromatograms of direct genomic sequencing for $\alpha$-thalassemia $\mathrm{Hb}$ Adana and $\mathrm{Hb}$ Adana trait. All 36 (26 $\alpha$-thalassemia intermedia with $\mathrm{Hb}$ Adana and $10 \mathrm{Hb}$ Adana 
trait) samples sequenced showed the $\mathrm{Hb}$ Adana mutation on the $\alpha 2$-globin gene instead of a1. To confirm the position of $\mathrm{Hb}$ Adana on the $\alpha 2$-globin gene, RFLP-PCR was done and the findings concurred with the DNA sequencing results obtained (Figure 2).

Table 1. Genotype frequencies, ethnicity, and the position of $\mathrm{Cd} 59$ on the $\alpha$-globin gene in $\mathrm{Hb}$ Adana cases.

\begin{tabular}{l|l|c|c|}
\hline Genotypes & Ethnicity (No. of patients) & Frequency & Position of Cd59 on $\alpha$-globin gene \\
\hline$-\alpha^{3.7 /} / \alpha^{C d 59} \alpha$ & Malay (21) Chinese (1) lban (2) & $24(66.7 \%)$ & $\alpha 2$ \\
\hline$-\alpha^{4.2} / \alpha^{C d 59} \alpha$ & Malay (2) & $2(5.6 \%)$ & $\alpha 2$ \\
\hline$\alpha \alpha / \alpha^{C d 59} \alpha$ & Malay (9) Chinese (1) & $10(27.8 \%)$ & $\alpha 2$ \\
\hline Total & & 36 & \\
\hline
\end{tabular}

${ }^{*}$ Frequency data are reported as the number of subjects with the frequency percentage in parentheses.

A

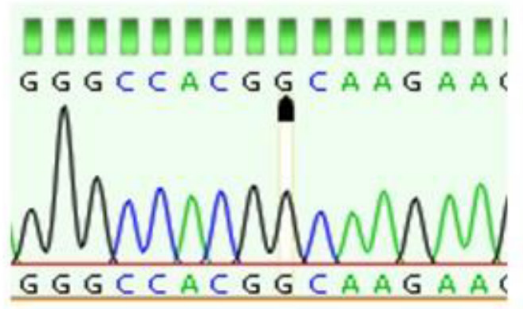

C

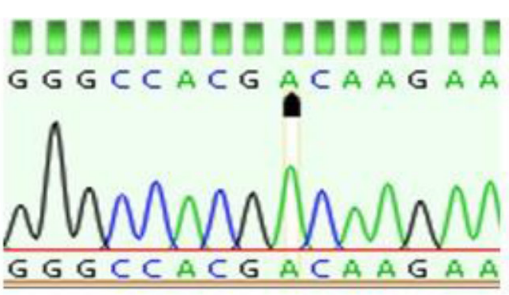

E

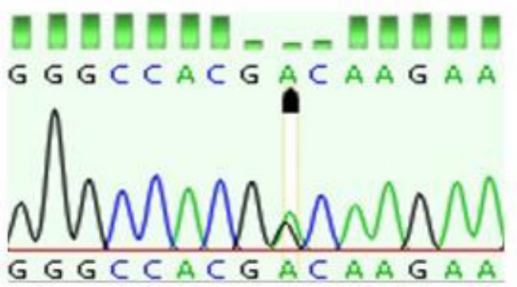

B

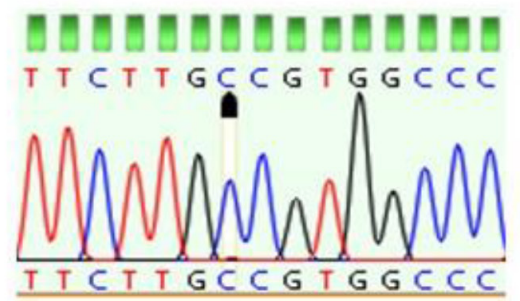

D

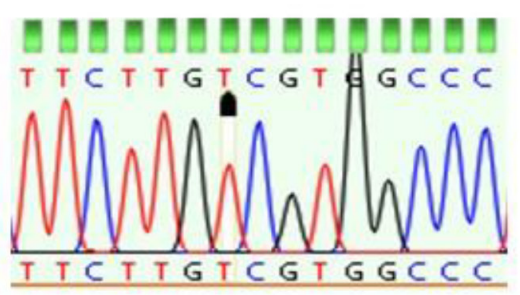

$\mathbf{F}$

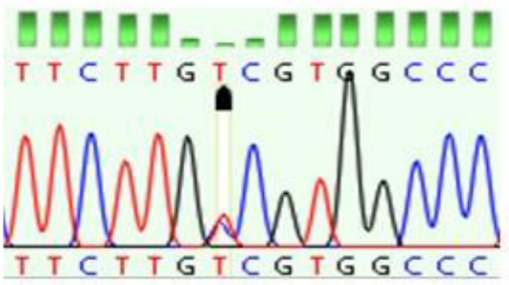

Figure 1. Chromatograms of direct genomic sequencing. A. Forward wild-type sequence for nucleotide $\mathrm{G}$ of the $\alpha 2-$ globin gene. B. Reverse wild-type sequence for nucleotide $C$ of the $\alpha 2$-globin gene. C. Forward mutant ( $\alpha$-thalassemia $\mathrm{Hb}$ Adana) sequence for nucleotide A on the $\alpha 2$-globin gene. D. Reverse mutant ( $\alpha$-thalassemia Hb Adana) sequence for nucleotide $\mathrm{T}$ on the $\alpha 2$-globin gene. E. Forward mutant ( $\mathrm{Hb}$ Adana trait) sequence on the $\alpha 2$-globin gene. Two peaks were detected at the same position for nucleotide $\mathrm{G}$ (wild-type allele) and nucleotide $\mathrm{A}$ (mutant allele) indicating a heterozygous state. F. Reverse mutant ( $\mathrm{Hb}$ Adana trait) sequence on the $\alpha 2$-globin gene. Two peaks were detected at the same position for nucleotide C (wild type-allele) and nucleotide T (mutant allele) indicating a heterozygous state. 
A

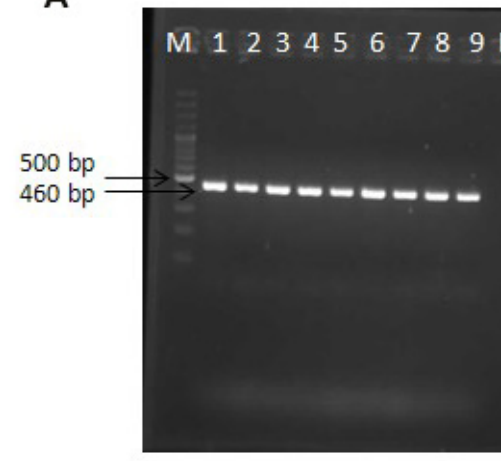

B

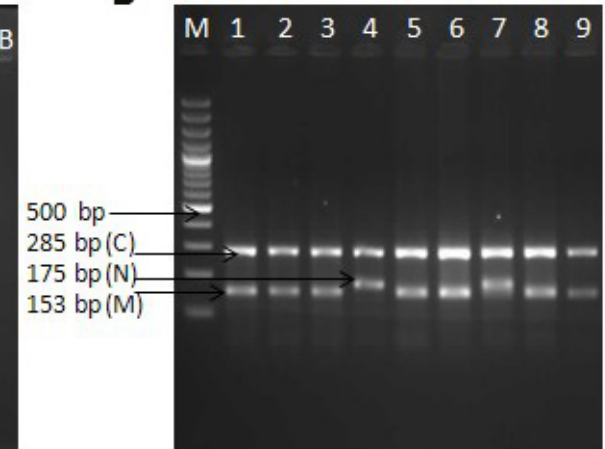

Figure 2. PCR-RFLP analysis of $\mathrm{Hb}$ Adana location on $\alpha 2$ globin gene. A. Undigested PCR products. B. Digested PCR products. Lanes 1-3, 5-6, and 8-9 = $\alpha$-thalassemia $\mathrm{Hb}$ Adana on $\alpha 2$. Lane 4 acts as positive control for wild type. Lane $7=\mathrm{Hb}$ Adana trait on $\alpha 2$. Lane $M=$ marker for ladder, $\mathrm{B}=\mathrm{Blank}, \mathrm{C}=$ constant band, $\mathrm{N}=$ normal band, and $\mathrm{M}=$ mutant band.

\section{DISCUSSION}

Malaysia has a multiracial population, which consists of 3 major ethnic groups: Malays, Chinese, and Indian. As of 2010, Malay and Chinese populations constituted 65 and $26 \%$ of the 28.6 million people in Malaysia, respectively, based on data from the Department of Statistics Malaysia (Department of Statistics Malaysia, 2010).

Adana is a large city in southern Turkey situated near the Seyhan River at the northeastern edge of the Mediterranean Sea. Major ethnic groups in Adana are Turks, Arabs, and Kurds. The first reported case of $\mathrm{Hb}$ Adana was found in a Turkish family and the Cd 59 mutation was located in $\alpha 1$ of the $\alpha$-globin gene complex. It was named $\mathrm{Hb}$ Adana since the first case was found in the Adana Province, Turkey (Cürük et al., 1993). Although the first case originated from Adana Province in Turkey, its frequency in that province itself is low (only $0.6 \%$ ) as reported by Bozdogan et al. (2015). Based on Table 2, all Hb Adana cases reported in Turkey so far are in the a1 globin gene whereas reports from other regions are all in the $\alpha 2$ globin gene (Cürük et al., 1993; Durmaz et al., 2009; Aksu et al., 2014; Bozdogan et al., 2015). In the past, the prevalence of $\mathrm{Hb}$ Adana carriers was not known in Malaysia as the identification of this mutation required DNA analysis, which is not widely available in Malaysia (Alauddin et al., 2014). In addition, $\mathrm{Hb}$ Adana trait is asymptomatic and is often overlooked in thalassemia screening programs when the full blood counts and red blood cell indices are normal (Setianingsih et al., 2003). Nainggolan et al. (2010) reported that the frequency of $\mathrm{Hb}$ Adana in Indonesia is relatively high, accounting for as much as $16 \%$ of thalassemia intermedia and thalassemia major patients. Hb Adana is not a rare mutation as previously reported since the frequency in both Indonesia and Malaysia located in South East Asia has been found to be quite high as determined using the available DNA diagnostic technology (Rahimah et al., 2012; Azma et al., 2014; Yatim et al., 2014; Zainal et al., 2014).

All the $\mathrm{Hb}$ Adana cases reported here share the same Cd 59 mutation located in the $\alpha 2$ globin gene, a feature similar to the cases seen in Indonesia. Our data reported herein is also in agreement with previous reports regarding the $\mathrm{Hb}$ Adana cases in Indonesia (Nainggolan et al., 2010; Nainggolan et al., 2013; Megawati et al., 2014). Both Malaysia and Indonesia are culturally 
related neighbors located in the same region. The migration between Indonesia and Malaysia resulted in a similar language (Bahasa Malaysia and Bahasa Indonesia), culture, and religion. Constant travel since antiquity, particularly between the coastal port cities of Sumatra in Indonesia and Peninsular Malaysia, for trade also explains the current $\mathrm{Hb}$ Adana mutation pool in Malaysia (Rahimah et al., 2012).

Table 2. Recently reported cases of Hb Adana from 1993-2014.

\begin{tabular}{|c|c|c|c|c|}
\hline Year (No. of cases) & Genotypes & Affected gene & Ethnicity & Reference \\
\hline $1993(2)$ & $--^{20.5} / \alpha \alpha^{\mathrm{CD} 59}$ & $\alpha 1$, exon 2 & Turkish & Cürük et al., 1993 \\
\hline 1997 & ${ }_{--}{ }^{\mathrm{SEA}} / \alpha^{\mathrm{CD} 59} \alpha$ & $\alpha 2$, exon 2 & Chinese & Chan et al., 1997 \\
\hline 2008 & $--{ }^{\mathrm{FIL}} / \alpha^{\mathrm{CD} 59} \alpha$ & $\alpha 2$, exon 2 & Filipino & Henderson et al., 2008 \\
\hline $2008(2)$ & $-\alpha^{3.7} / \alpha^{\mathrm{CD} 59} \alpha$ & $\alpha 2$, exon 2 & Albanian & Douna et al., 2008 \\
\hline 2009 & $--^{20.5} / \alpha \alpha^{\mathrm{CD} 59}$ & $\alpha 1$, exon 2 & Turkish & Durmaz et al., 2009 \\
\hline $2010(2)$ & $\alpha^{\mathrm{CD} 59} \alpha / \alpha^{\mathrm{CD} 59} \alpha$ & $\alpha 2$, exon 2 & Javanese & Nainggolan et al., 2010 \\
\hline $2013(17)$ & $-\alpha^{3.7 /} / \alpha^{\mathrm{CD} 59} \alpha$ & $\alpha 2$, exon 2 & Indonesian & Nainggolan et al., 2013 \\
\hline 2013 & $-\alpha^{4.2} / \alpha^{\mathrm{CD} 59} \alpha$ & $\alpha 2$, exon 2 & Indonesian & Nainggolan et al., 2013 \\
\hline $2013(4)$ & $\alpha^{\mathrm{CD} 59} \alpha / \alpha \alpha^{\mathrm{CS}}$ & $\alpha 2$, exon 2 & Indonesian & Nainggolan et al., 2013 \\
\hline $2013(3)$ & $\alpha^{\mathrm{CD} 59} \alpha / \alpha \alpha^{\mathrm{CD} 22}$ & $\alpha 2$, exon 2 & Indonesian & Nainggolan et al., 2013 \\
\hline 2013 & $\alpha^{\mathrm{CD} 59} \alpha / \alpha \alpha^{\mathrm{rSNP}}$ & $\alpha 2$, exon 2 & Indonesian & Nainggolan et al., 2013 \\
\hline 2013 & $\alpha^{\mathrm{CD} 59} \alpha / \alpha \alpha^{\mathrm{II-142}}$ & $\alpha 2$, exon 2 & Indonesian & Nainggolan et al., 2013 \\
\hline 2013 & $\alpha^{\mathrm{CD} 59} \alpha / \alpha \alpha^{\mathrm{CD} 24}$ & $\alpha 2$, exon 2 & Sudanese & Megawati et al., 2014 \\
\hline $2014(2)$ & $\alpha^{\mathrm{CD} 59} \alpha / \alpha \alpha^{\mathrm{CS}}$ & $\alpha 2$, exon 2 & Malay & Alauddin et al., 2014 \\
\hline $2014(2)$ & $-\alpha^{3.7 /} \alpha^{\mathrm{CD} 59} \alpha$ & $\alpha 2$, exon 2 & Malay & Alauddin et al., 2014 \\
\hline 2014 & $\alpha \alpha^{\mathrm{CD} 59 / \alpha \alpha^{\mathrm{CD} 59}}$ & $\alpha 1$, exon 2 & Turkish & Aksu et al., 2014 \\
\hline 2015 & $-\alpha^{3.7 / \alpha^{C D} 59} \alpha$ & $\alpha 1$, exon 2 & Turkish & Bozdogan et al., 2015 \\
\hline $2015(3)$ & $\alpha^{\mathrm{CD} 59} \alpha / \alpha \alpha$ & $\alpha 1$, exon 2 & Turkish & Bozdogan et al., 2015 \\
\hline
\end{tabular}

$\mathrm{Hb}$ Adana reported in Turkey is different from that described in Indonesia and Malaysia in terms of the position of $\mathrm{Cd} 59$ in the $\alpha$-globin gene complex. The cases reported in Turkey involved $\alpha 1$ and not $\alpha 2$ of the $\alpha$-globin gene complex. $\alpha$-thalassemia is diverse as the mutations are varied among populations due to natural selection along with some degree of founder effect and genetic drift (Higgs and Weatherall, 2009). Hb S is a $\beta$-globin chain variant with multicentric origins. The majority of the people who inherited hemoglobinopathy are African, as well as those from the Middle East and India. Similarly, $\mathrm{Hb}$ Adana may have more than one origin (Europe and Southeast Asia), which may explain its position in either $\alpha 1$ or $\alpha 2$ globin genes.

The results of this study should be interpreted in the context of the study's limitations. Haplotyping studies on the $\alpha$-globin gene should be done on the Hb Adana patients to compare and trace the origins of different populations from different regions. This will facilitate the study of the $\alpha$-globin gene flow among various populations using phylogenetics, among both the Turkish and non-Turkish population. Hb Adana among Malays in Malaysia might have the same ancestry based on the similarities of the $\mathrm{Cd} 59$ position. Definitive diagnosis is dependent on the DNA analysis and we strongly recommend that DNA analysis is incorporated as part of the routine $\alpha$-thalassemia screening programs carried out by the National Prevention and Control Programme for thalassemia patients in Malaysia. By doing so, appropriate genetic counselling can be given to couples or families with a risk of $\alpha$-thalassemia $\mathrm{Hb}$ Adana.

\section{Conflicts of interest}

The authors declare no conflict of interest. 


\section{ACKNOWLEDGMENTS}

The authors wish to thank the Director General of Health, Malaysia for permission to publish this paper [\#NMRR-12-1387-13958]. Research supported by a Fundamental Research Grant Scheme (FRGS; \#02-01-12-1124 FR) and Research University Grant Scheme Universiti Putra Malaysia (RUGS-UPM; \#04-02-12-2100RU) awarded to Elizabeth George.

\section{REFERENCES}

Aksu T, Yarali N, Bayram C, Fettah A, et al. (2014). Homozygosity for HBA1: c.179G > A: Hb Adana in an infant. Hemoglobin 38: 449-450. http://dx.doi.org/10.3109/03630269.2014.969373

Alauddin H, Jaapar NA, Azma RZ, Ithnin A, et al. (2014). A case series of $\alpha$-thalassemia intermedia due to compound heterozygosity for Hb Adana [HBA2: c179G>A (or HBA1); p.Gly60Asp] with other $\alpha$-thalassemias in Malay families. Hemoglobin 38: 277-281. http://dx.doi.org/10.3109/03630269.2014.916720

Azma RZ, Ainoon O, Hafiza A, Azlin I, et al. (2014). Molecular characteristic of alpha thalassaemia among patients diagnosed in UKM Medical Centre. Malays. J. Pathol. 36: 27-32.

Bain BJ (2006). Haemoglobinopathy Diagnosis. 2nd ed. Blackwell Publishing Ltd., Oxford, UK.

Bozdogan ST, Yuregir OO, Buyukkurt N, Aslan H, et al. (2015). Alpha-thalassemia mutations in adana province, southern Turkey: genotype-phenotype correlation. Indian J. Hematol. Blood Transfus. 31: 223-228. http://dx.doi.org/10.1007/ s12288-014-0406-0

Chan V, Chan VW, Tang M, Lau K, et al. (1997). Molecular defects in Hb H hydrops fetalis. Br. J. Haematol. 96: 224-228. http:// dx.doi.org/10.1046/j.1365-2141.1997.d01-2017.x

Chong SS, Boehm CD, Higgs DR and Cutting GR (2000). Single-tube multiplex-PCR screen for common deletional determinants of a-thalassemia. Blood 95: 360-362.

Cürük MA, Dimovski AJ, Baysal E, Gu LH, et al. (1993). Hb Adana or $\left.\alpha_{21} 59\right)(E 8) G l y \rightarrow$ Asp $\beta$ 2, a severely unstable $\alpha$ 1-globin variant, observed in combination with the -( $\alpha) 20.5 \mathrm{~Kb}$ a-thal-1 deletion in two Turkish patients. Am. J. Hematol. 44: 270275. http://dx.doi.org/10.1002/ajh.2830440410

Department of Statistics Malaysia (2010). Population Distribution and Basic Demographic Characteristics Report. Available at [http://www.statistics.gov.my]. Accessed July 21, 2015.

Douna V, Papassotiriou I, Garoufi A, Georgouli E, et al. (2008). A rare thalassemic syndrome caused by interaction of $\mathrm{Hb}$ Adana [a59(E8)Gly-->Asp] with an a+-thalassemia deletion: clinical aspects in two cases. Hemoglobin 32: 361-369. http:// dx.doi.org/10.1080/03630260802173890

Durmaz AA, Akin H, Ekmekci AY, Onay H, et al. (2009). A severe a thalassemia case compound heterozygous for $\mathrm{Hb}$ Adana in $\alpha 1$ gene and 20.5 kb double gene deletion. J. Pediatr. Hematol. Oncol. 31: 592-594. http://dx.doi.org/10.1097/ MPH.0b013e3181a71855

Eng B, Patterson M, Walker L, Chui DH, et al. (2001). Detection of severe nondeletional $\alpha$-thalassemia mutations using a single-tube multiplex ARMS assay. Genet. Test. 5: 327-329. http://dx.doi.org/10.1089/109065701753617471

George E and Ann TJ (2010). Genotype-phenotype diversity of beta-thalassemia in Malaysia: treatment options and emerging therapies. Med. J. Malaysia 65: 256-260.

Henderson S, Pitman M, McCarthy J, Molyneux A, et al. (2008). Molecular prenatal diagnosis of $\mathrm{Hb} \mathrm{H}$ hydrops fetalis caused by haemoglobin Adana and the implications to antenatal screening for $\alpha$-thalassaemia. Prenat. Diagn. 28: 859-861. http:// dx.doi.org/10.1002/pd.2045

Higgs DR and Weatherall DJ. (2009). The alpha thalassaemias. Cell Mol. Life Sci. 66: 1154-1162.

Liebhaber SA, Cash FE and Ballas SK (1986). Human alpha-globin gene expression. The dominant role of the alpha 2-locus in mRNA and protein synthesis. J. Biol. Chem. 261: 15327-15333.

Megawati D, Nainggolan IM, Swastika M, Susanah S, et al. (2014). Severe $\alpha$-thalassemia intermedia due to a compound heterozygosity for the highly unstable $\mathrm{Hb}$ Adana (HBA2: c.179G>A) and a novel codon 24 (HBA2: c.75T>A) mutation. Hemoglobin 38: 149-151. http://dx.doi.org/10.3109/03630269.2013.863206

Nainggolan IM, Harahap A and Setianingsih I (2010). Hydrops fetalis associated with homozygosity for Hb Adana [alpha59(E8) Gly-->Asp (alpha2)]. Hemoglobin 34: 394-401. http://dx.doi.org/10.3109/03630269.2010.493405

Nainggolan IM, Harahap A, Ambarwati DD, Liliani RV, et al. (2013). Interaction of Hb adana (HBA2: c. 179G >A) with deletional and nondeletional $\alpha(+)$-thalassemia mutations: diverse hematological and clinical features. Hemoglobin 37: 297-305. http://dx.doi.org/10.3109/03630269.2013.775149 
Rahimah AN, Nisha S, Safiah B, Roshida H, et al. (2012). Distribution of alpha thalassaemia in 16 year old Malaysian Students in Penang, Melaka and Sabah. Med. J. Malaysia 67: 565-570.

Setianingsih I, Harahap A and Nainggolan IM (2003). a thalassaemia in Indonesia: phenotypes and molecular defects. Adv. Exp. Med. Biol. 531: 47-56. http://dx.doi.org/10.1007/978-1-4615-0059-9 4

Weatherall D (1995). The molecular basis for phenotypic variability of the common thalassaemias. Mol. Med. Today 1: 15-20. http://dx.doi.org/10.1016/1357-4310(95)80014-X

Yatim NF, Rahim MA, Menon K, Al-Hassan FM, et al. (2014). Molecular characterization of $\alpha$ - and $\beta$-thalassaemia among Malay patients. Int. J. Mol. Sci. 15: 8835-8845. http://dx.doi.org/10.3390/ijms15058835

Zainal NZ, Alauddin H, Ahmad S and Hussin NH (2014). a-Thalassemia with Haemoglobin Adana mutation: prenatal diagnosis. Malays. J. Pathol. 36: 207-211. 